American J. of Engineering and Applied Sciences 1 (3): 230-240, 2008

ISSN 1941-7020

(C) 2008 Science Publications

\title{
Treatment of Remazol Brilliant Blue Dye Effluent by Advanced Photo Oxidation Process in $\mathrm{TiO}_{2} / \mathrm{UV}$ and $\mathrm{H}_{2} \mathrm{O}_{2} / \mathrm{UV}$ reactors
}

\author{
M. Verma and A.E. Ghaly \\ Department of Process Engineering and Applied Science, Dalhousie University \\ Halifax, Nova Scotia, Canada B3J 2X4
}

\begin{abstract}
Advanced oxidation processes involving $\mathrm{TiO}_{2} / \mathrm{UV}$ and $\mathrm{H}_{2} \mathrm{O}_{2} / \mathrm{UV}$ were evaluated for their potential use in decolorization of textile dye effluents. A coil photo reactor, consisting of UV radiation source and a spiral coil coated with $\mathrm{TiO}_{2}$, was used to treat synthetic effluent of Remazol Brilliant Blue dye. The $\mathrm{TiO}_{2}$ coating was performed using the sol-gel technique. The effects of $\mathrm{UV}$ radiation, $\mathrm{TiO}_{2}$ coatings and dye concentration were studied and the results were compared to dye treatment involving $\mathrm{H}_{2} \mathrm{O}_{2}$. The maximum dye removal efficiencies were 7.3, 12.2 and $12.5 \%$ for uncoated, single coat and dual coat of $\mathrm{TiO}_{2}$, respectively. The decolorization efficiency was inversely related to dye concentration of the effluent. The treatments with UV only, $\mathrm{TiO}_{2}$ only, $\mathrm{UV}+\mathrm{TiO}_{2}, \mathrm{H}_{2} \mathrm{O}_{2}$ only and $\mathrm{UV}+\mathrm{H}_{2} \mathrm{O}_{2}$ resulted in color reduction of 7.6, 2.3, 12.5, 4.1 and $99.9 \%$ respectively. The maximum decolorization occurred in $\leq 100 \mathrm{~min}$ in all cases. The temperature varied from 29.2 to $54.7^{\circ} \mathrm{C}$ for $\mathrm{UV}+\mathrm{TiO}_{2}$ treatment and no change in reactor temperature was observed when $\mathrm{UV}$ was not used.
\end{abstract}

Key words: Advanced oxidation, coil reactor, decolorization efficiency, Remazol Brilliant Blue, textile dye effluent, $\mathrm{TiO}_{2}$ coating, UV radiation.

\section{INTRODUCTION}

Textile industries generate 100-170 L dye effluent per kg of cloth processed, which could be characterized by strong color, high COD and wide range of $\mathrm{pH}^{[1]}$. Synthetic dye effluents emerging from various industrial operations pose great threat to the environment due to risks of toxicity to aquatic organisms in natural water resources and inhibition of photosynthetic activity ${ }^{[2]}$. Existing non-destructive treatment methods for industrial effluents comprise various chemical and physical processes, such as chemical-coagulation, electro-coagulation, reverse osmosis, nanofiltration and adsorption ${ }^{[3-8]}$. However, these methods concentrate the dye pollutants and necessitate secondary treatment. On the other hand, degradation involving biological processes is not efficient as the synthetic dyes in the effluent are highly structured polymers with low biodegradability ${ }^{[9-10]}$.

Use of conventional dye wastewater treatment methods are becoming increasingly challenging for existing plants due to recent guidelines adopted by water authorities. The US Department of Commerce has projected a 3.5 -fold increase in textile production between 1975 and $2020^{[11]}$. This also indicates that in order to attain this target, the synthetic dyes would be continually upgraded in terms of both quality and quantity, which would lead to further deterioration of the environment. Current conventional processes sometimes also lead to production of derivative compounds due to reduction under anaerobic conditions which could pose more severe hazard in contrast to original dye ${ }^{[12]}$. In order to address these limitations, various researchers have proposed advanced oxidation processes (ozone, $\mathrm{H}_{2} \mathrm{O}_{2}, \mathrm{TiO}_{2}, \mathrm{ZnO}, \mathrm{RuO}_{2}, \mathrm{SiO}_{2}, \mathrm{UV}$ radiation, electron-beam irradiation, super critical water, wet air, catalytic wet air and ultrasound) as plausible option for efficient removal of color pollutants from contaminated water ${ }^{[13-16]}$.

Amongst advanced oxidation methods, $\mathrm{TiO}_{2} / \mathrm{UV}$ radiation mediated process hold substantial promise for efficient and complete removal of many synthetic dyes as $\mathrm{TiO}_{2}$ is the most extensively used photocatalyst ${ }^{[14,16-20]}$. $\quad \mathrm{TiO}_{2} / \mathrm{UV}$ radiation mediated process lead to heterogeneous photocatalysis, one of the advanced oxidation processes (AOPs). It is an efficient wastewater treatment technique which could result into total mineralization of organics ${ }^{[21]}$. It has been suggested that the valence band holes generated by UV photons interact with $\mathrm{H}_{2} \mathrm{O}$ or $\mathrm{OH}-$ adsorbed on the catalyst $\left(\mathrm{TiO}_{2}\right)$ surface to generate $\cdot \mathrm{OH}$ radical, or with

Corresponding Author: Abdel Ghaly, Department of Process Engineering and Applied Science, Dalhousie University, Halifax, Nova Scotia, Canada B3J 2X4; Tel: (902) 494-6014; Fax: (902) 423-2423 
adsorbed $\mathrm{O}_{2}$ (on the catalyst surface) to yield $\cdot \mathrm{O}_{2}-$ and $\cdot \mathrm{OOH}$ radicals ${ }^{[22,23]}$.

The present study was performed to investigate the effect of $\mathrm{TiO}_{2}$ mediated oxidation of Remazol Brilliant Blue dye under various reaction conditions. The effects of $\mathrm{TiO}_{2}$ coating, $\mathrm{UV}$ radiation and dye concentration on decolorization of dye were studied. Steady-state temperature at different locations of the $\mathrm{TiO}_{2} / \mathrm{UV}$ reactor and $\mathrm{pH}$ profiles of inlet and outlet dye effluents were also measured. In addition, in order to obtain $\mathrm{TiO}_{2}$ film on the stainless steel coil used in $\mathrm{TiO}_{2} / \mathrm{UV}$ reactor, the sol-gel technique was explored. The effects of $\mathrm{H}_{2} \mathrm{O}_{2}$ addition and $\mathrm{H}_{2} \mathrm{O}_{2}$ only were also investigated and the results were compared with the $\mathrm{TiO}_{2}$ experiments.

\section{MATERIALS AND METHODS}

Experimental set-up: The experimental set-up (Fig. 1) consisted of a synthetic dye wastewater feeding and effluent collection system, $\mathrm{TiO}_{2} / \mathrm{UV}$ reactors, temperature sensors, pumps and a data acquisition system. The synthetic dye wastewater feeding and effluent collection system consisted of Remazol brilliant blue dye feeding tank, a peristaltic pumps and an effluent collection tank. The dye feeding and effluent collection tanks were made of $4 \mathrm{~mm}$ thick Plexiglas pipe of a $200 \mathrm{~mm}$ internal diameter and a $435 \mathrm{~mm}$ height with volume of about $11 \mathrm{~L}$. The detachable cover and the fixed bottom of each tank were made from $4 \mathrm{~mm}$ thick Plexiglas circular plates. A $4 \mathrm{~mm}$ diameter port was located on the cover to allow air inlet for pressure equalization during pumping out of the dye wastewater from the tank. The outlet port (4 $\mathrm{mm}$ diameter) of the feeding tank was located at 15 $\mathrm{mm}$ from the bottom. An agitator having stirring blades ( $1.5 \mathrm{~mm}$ thick and $72 \mathrm{~mm}$ in length) of $9 \mathrm{~mm}$ diameter and $370 \mathrm{~mm}$ length was installed at the center of the

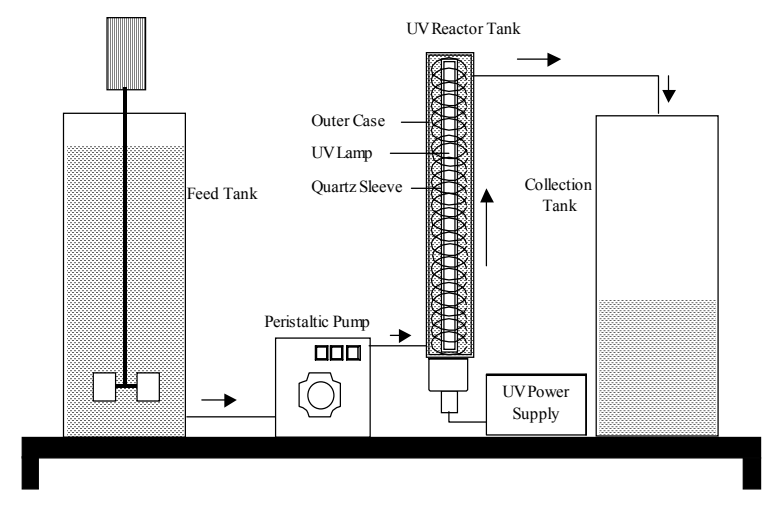

Fig. 1: $\mathrm{TiO}_{2} / \mathrm{UV}$ coil reactor setup feeding tank cover and used to mix the dye. The agitator was driven by an electric motor (model NSI-1 ORS3, Bodine Electric Company, Chicago, IL USA.) mounted on top of the feeding tank cover. Two variable speed peristaltic pumps and Masterflex precision tubings (Digi-Staltic, Masterflex Model 7253-60, head model 77200-50, tubing no. MasterFlex ${ }^{\circledR}$ 6404-14 and MasterFlex ${ }^{\circledR}$ 6404-13, Barnant Company, Division of Cole Parmer Instrument.Co., Barrington, IL.) were used. The peristaltic pumps pumped the synthetic dye wastewater from the feeding tank into the $\mathrm{TiO}_{2} / \mathrm{UV}$ reactors at the required flow rates.

The photo $\left(\mathrm{TiO}_{2} / \mathrm{UV}\right)$ reactor is shown in Fig. 2. Low pressure mercury lamps with $380 \mathrm{~mm}$ arc length, enclosed in a $21 \mathrm{~mm}$ outside diameter quartz tube, were

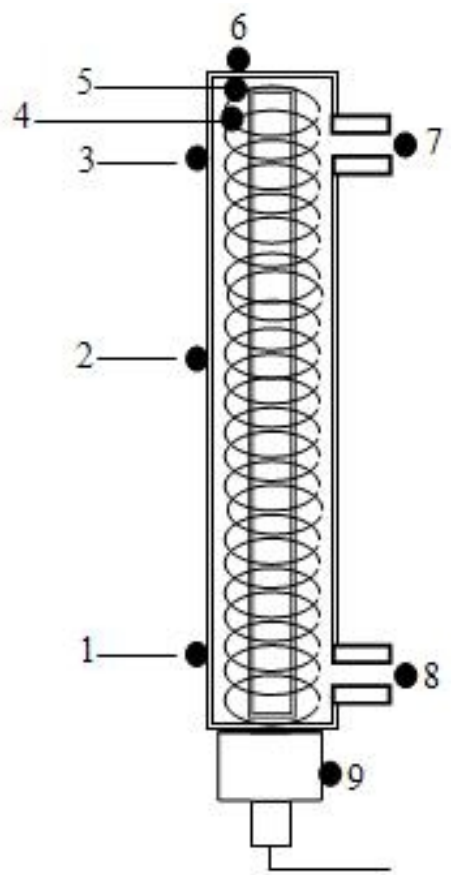

1: Temperature on the outside surface of the reactor opposite to inlet

2: Temperature on the outside surface of the reactor at the mid height

3: Temperature on the outside surface of the reactor opposite to outlet

4: Temperature of the reactor head space

5: The inside temperature of the reactor top

6: Temperature on the outside surface of the reactor top

7: The outlet dye temperature

8: The inlet dye solution temperature

9: The temperature of the lamp socket surface

Fig. 2: Thermocouple locations in the coil reactors 
used in the reactors. The inner and the outer diameters of both reactors are 55 and $61 \mathrm{~mm}$, respectively. The $3 \mathrm{~mm}$ thick stainless steel chamber provided a gap size (distance between the quartz sleeve and the inner surface of reactor casing) of $17 \mathrm{~mm}$ in both reactors. Coils made of stainless steel with a length of $448 \mathrm{~mm}$ a thickness of $0.85 \mathrm{~mm}$, an internal diameter of $21 \mathrm{~mm}$ and a pitch of $20 \mathrm{~mm}$ were used in the reactors. The working volume in each reactor was $840 \mathrm{~mL}$.

A digital data logger (Model 4702-5 E, Cole Parmer, Chicago, IL, USA) and type T thermocouples (Model 8530-75, Cole Parmer instrument company, Chicago, IL, USA) were used in the study to measure the temperature at different sites on the reactors. The thermocouples were placed at nine locations in each reactor (Fig. 2). The temperature sensors (type $T$ thermocouples) were calibrated using ice bath and boiling deionized distilled water. The thermocouples were connected to the data acquisition system individually in different channels and immersed into the ice bath. The thermocouple reading, as temperature in degrees centigrade, was corrected to read zero (offset). The thermocouples were then immersed into the boiling water to calibrate the upper limit. The accuracy of the thermocouples was found to be $\pm 0.4^{\circ} \mathrm{C}$.

Chemicals: The chemicals used in this study included hydrogen peroxide, Remazol brilliant blue dye, absolute alcohol, tetrabuthylorthotitanate $\left(\mathrm{Ti}(\mathrm{OBu})_{4}\right)$ and diethanolamine $\left(\mathrm{NH}\left(\mathrm{C}_{2} \mathrm{H}_{4} \mathrm{OH}\right)_{2}\right)$. The hydrogen peroxide $\left(\mathrm{H}_{2} \mathrm{O}_{2}, 30 \%\right)$ was obtained from Fisher scientific (Ca \# H-325-500, Fisher scientific, Montreal, Quebec, Canada). The Remazol brilliant blue dye $\sim 50 \%$ (1-amino-4-[4-(1-sulfonyl-ethyl-2-sulfoxy)]-2-(9, 10anthraquinone)-sulfonic acid; disodium salt) was obtained from Sigma (R8001, CAS \# 2580-78-1, Sigma-Aldrich Inc., St-Louis, MO, USA). The molecular formula of the dye is $\mathrm{C}_{22} \mathrm{H}_{16} \mathrm{~N}_{2} \mathrm{Na}_{2} \mathrm{O}_{11} \mathrm{~S}_{3}$ and the structural formula is shown in Fig. 3. Anhydrous ethyl alcohol (100\% ethanol) was obtained from Commercial Alcohols Inc., Brampton, Ontario, Canada.

Standard curve: In order to determine the concentration of the Remazol brilliant blue dye using the colorimetric techniques, a standard curve was generated from the standard solution of Remazol brilliant blue dye according to the procedure described by Mahmoud et al. ${ }^{[19]}$. According to this procedure, the standard solution was prepared by dissolving $0.1 \mathrm{~g}$ of the dye in $1000 \mathrm{~mL}$ of distilled deionized water at ambient conditions ( $\mathrm{pH} 7$ and $25^{\circ} \mathrm{C}$ ). Then, a set of nine solutions with Remazol blue dye concentrations of 10 , $20,30,40,50,60,70,80$ and $100 \mathrm{mg} \mathrm{L}^{-1}$ were

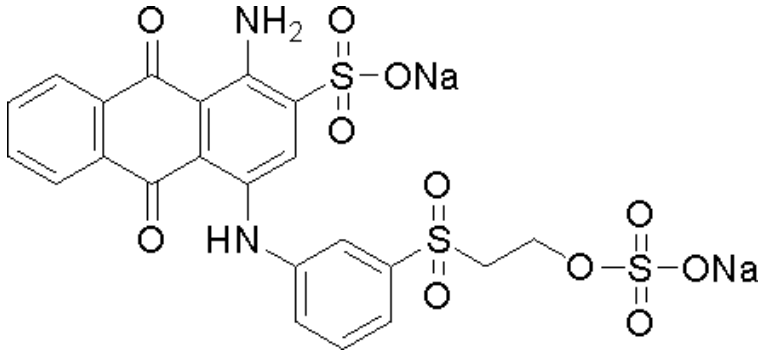

Fig. 3: Molecular structure of remazol brilliant blue $\mathrm{R}$ dye

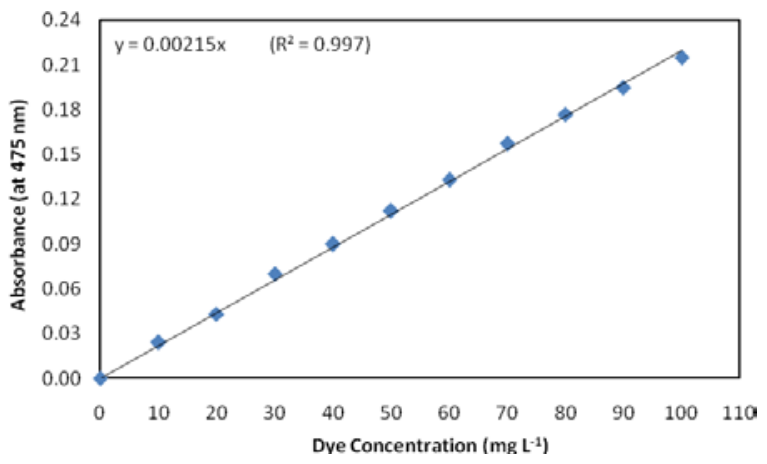

Fig. 4: Absorbance curve for remazol brilliant blue dye solution $\left(\mathrm{pH}=7,25^{\circ} \mathrm{C}\right)$

prepared. Finally, the absorbance of the solutions thus prepared was measured (in triplicates) using spectrophotometer at $420 \mathrm{~nm}$ (Spectronic 601, Fisher scientific, Montreal, Quebec, Canada). The absorbance was then plotted against the known Remazol blue dye concentrations ( $\left.\mathrm{mg} \mathrm{L}^{-1}\right)$ as shown in Fig. 4. A blank sample using distilled deionized water was used to zero the spectrophotometer.

Sol-gel coating on stainless steel coils: The sol-gel coating was prepared according to the procedure described by Giornelli et al. ${ }^{[24]}$ as shown in Fig. 5. For this, $17.2 \mathrm{~mL}$ of tetrabuthylorthotitanate $\left(\mathrm{Ti}(\mathrm{OBu})_{4}\right)$ $97 \%$ and $4.8 \mathrm{~mL}$ of diethanolamine $\left(\mathrm{NH}\left(\mathrm{C}_{2} \mathrm{H}_{4} \mathrm{OH}\right)_{2}\right)$ $99 \%$ were dissolved in $67.28 \mathrm{~mL}$ anhydrous ethyl alcohol. The resulting solution was mixed vigorously at room temperature for $2 \mathrm{~h}$ on a magnetic stirrer. About $2.7 \mathrm{~mL}$ of water and $10 \mathrm{ML}$ of ethanol $\left(\mathrm{Ti}(\mathrm{OBu})_{4}: \mathrm{C}_{2} \mathrm{H}_{5} \mathrm{OH}: \mathrm{H}_{2} \mathrm{O}: \mathrm{NH}\left(\mathrm{C}_{2} \mathrm{H}_{4} \mathrm{OH}\right)_{2}=1: 25.5: 3: 1\right.$, molar ratio) were added dropwise to the mixing solution. The resultant alkoxide sols thus formed were left standing at room temperature for $2 \mathrm{~h}$ for the hydrolysis reaction to proceed. $\mathrm{TiO}_{2}$ films on the stainless steel coil were prepared by dipping (15 min) and withdrawing the coil at a rate of $6 \mathrm{~mm} \mathrm{sec}^{-1}$. The 
Am. J. Engg. \& Applied Sci., 1 (3): 230-240, 2008

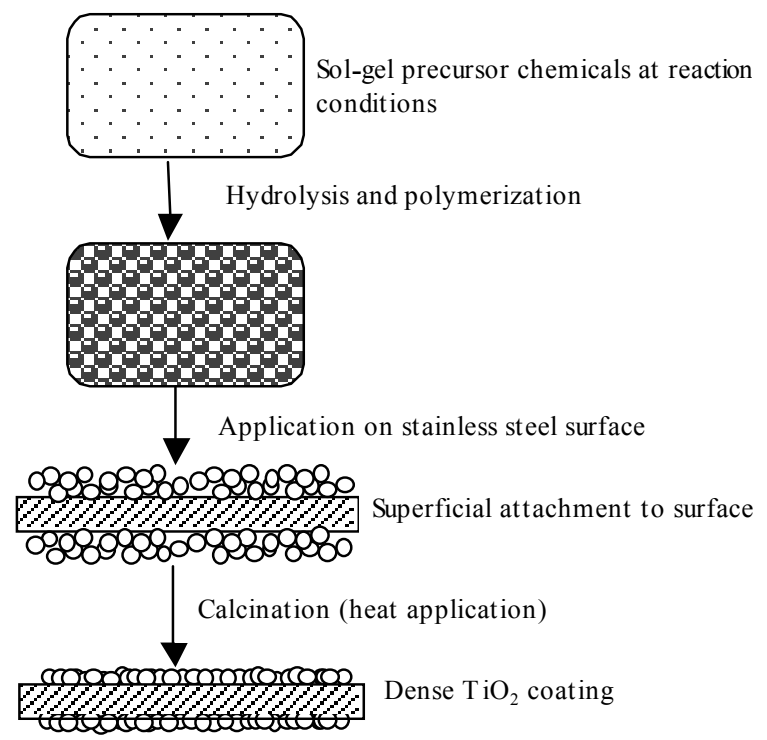

Fig. 5: Sol-gel process for $\mathrm{TiO}_{2}$ coating on stainless steel $^{[24]}$

resulting $\mathrm{TiO}_{2}$ films coated stainless steel coil was calcined in a furnace at $80^{\circ} \mathrm{C} \mathrm{h}^{-1}$, up to $100^{\circ} \mathrm{C}$ during $1 \mathrm{~h}$ and then at $900^{\circ} \mathrm{C}$ for $2 \mathrm{~h}$.

Experimental plan: Four sets of experiments were conducted in this study. The first set of experiments was carried out to study the effects of using UV radiation only (no $\mathrm{TiO}_{2}$ coating) on the decolorization of Remazol brilliant blue. The coil reactor was operated at a dye concentration of $300 \mathrm{mg} \mathrm{L}^{-1}$ and ten residence times $(840.0,168.0,84.0,56.0,42.0,28.0,21.0,16.8$, 14.0 and $8.4 \mathrm{~min}$ ) which gave flow rates of $1,5,10,15$,

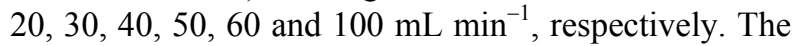
dye solution was fed into the reactor at ambient temperature $\left(25^{\circ} \mathrm{C}\right)$. The sample collection was performed after a minimum of $840 \mathrm{~mL}$ of dye effluent was pumped through the reactor.

In the second set of experiments, the effectiveness of the $\mathrm{TiO}_{2}$ coated coil reactor (different coatings) with UV radiation in removal of Remazol Brilliant Blue dye was evaluated. The coil reactor was operated at a dye concentration of $300 \mathrm{mg} \mathrm{L}^{-1}$ and ten residence times $(840.0,168.0,84.0,56.0,42.0,28.0,21.0,16.8,14.0$ and $8.4 \mathrm{~min}$ ) which gave flow rates of $1,5,10,15,20$, $30,40,50,60$ and $100 \mathrm{~mL} \mathrm{~min}^{-1}$, respectively. The dye solution was fed into the reactor at ambient temperature $\left(25^{\circ} \mathrm{C}\right)$. The sample collection was performed after a minimum of $840 \mathrm{~mL}$ of dye effluent was pumped through the reactor.
The third set of experiments was carried out to study the effect of dye concentration (100, 200 and $300 \mathrm{mg} \mathrm{L}^{-1}$ ) on the decolorization of Remazol brilliant blue using $\mathrm{TiO}_{2}$ coated coil reactor without UV radiation. The coil reactor was operated at ten residence times $(840.0,168.0,84.0,56.0,42.0,28.0,21.0,16.8$, 14.0 and $8.4 \mathrm{~min}$ ) which gave flow rates of $1,5,10,15$, $20,30,40,50,60$ and $100 \mathrm{~mL} \mathrm{~min}^{-1}$, respectively. The dye solutions were fed into the reactor at ambient temperature $\left(25^{\circ} \mathrm{C}\right)$. The sample collection was performed after a minimum of $840 \mathrm{~mL}$ of dye effluent was pumped through the reactor.

The fourth set of experiments was carried out to study the effect of using $\mathrm{H}_{2} \mathrm{O}_{2}$ (at $12.5 \mathrm{~mL} \mathrm{~L}^{-1}$ ) only on the decolorization of Remazol brilliant blue at different dye concentrations $\left(100,200\right.$ and $\left.300 \mathrm{mg} \mathrm{L}^{-1}\right)$. The coil reactor was operated at ten residence times $(840.0$, $168.0,84.0,56.0,42.0,28.0,21.0,16.8,14.0$ and 8.4 min) which gave flow rates of $1,5,10,15,20,30,40$, 50,60 and $100 \mathrm{~mL} \mathrm{~min}^{-1}$, respectively. The dye solutions were fed into the reactor at ambient temperature $\left(25^{\circ} \mathrm{C}\right)$. The sample collection was performed after a minimum of $840 \mathrm{~mL}$ of dye effluent was pumped through the reactor.

Experimental procedure: The Remazol brilliant blue dye solutions $\left(100,200\right.$ and $\left.300 \mathrm{mg} \mathrm{L}^{-1}\right)$ were prepared by dissolving the dye (2, 4 and $6 \mathrm{~g}$, respectively) in 20 $\mathrm{L}$ of deionized distilled water. The $\mathrm{pH}$ of the dye solutions were near 7. The dye solution (with and without $\mathrm{H}_{2} \mathrm{O}_{2}$ ) was pumped through the reactors at the required flow rates using the precalibrated peristaltic pumps (Digi-Staltic, Masterflex model 7253-60, head Model 77200-50, tubing no. MasterFlex ${ }^{\circledR}$ 6404-13 and MasterFlex ${ }^{\circledR}$ 6404-14, Barnant Company, Division of Cole Parmer Instrument. Co., Barrington, IL, USA), with the UV lamps in place. The UV lamps were kept on or off depending upon the experiment. The temperature readings were noted down from the data logger. Once the reactor was filled with dye solution, it was left to reach steady state (constant temperature). Samples were collected during the steady state from the reactor outlet. The absorbance of the dye solution samples was measured using a spectrophotometer (Spectronic 601, Fisher scientific, Montreal, Quebec, Canada) at a wave length of $475 \mathrm{~nm}$.

\section{RESULTS AND DISCUSSION}

UV radiation only: The decolorization efficiency profile for coil reactor with UV radiation only (no oxidant) is shown in Fig. 6 . The reactor was operated at 
Am. J. Engg. \& Applied Sci., 1 (3): 230-240, 2008

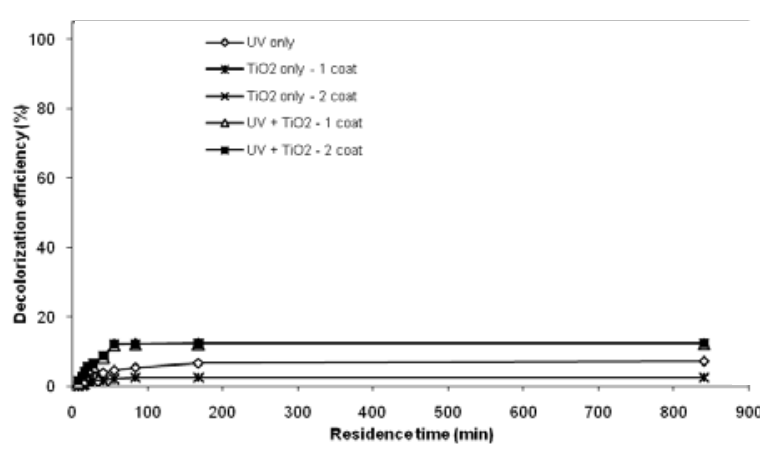

Fig. 6: Effect of UV radiation and $\mathrm{TiO}_{2}$ coating on decolorization at a dye concentration of $300 \mathrm{mg} \mathrm{L}^{-1}$

a dye concentration of $300 \mathrm{mg} \mathrm{L} \mathrm{L}^{-1}$, a $\mathrm{pH}$ of 7 , a temperature of $25^{\circ} \mathrm{C}$ and ten different residence times $(840.0,168.0,84.0,56.0,42.0,28.0,21.0,16.8,14.0$ and $8.4 \mathrm{~min}$ ). Initially, the decolorization efficiency increased with increase in residence time reaching $7.3 \%$ at a residence time of $56 \mathrm{~min}$. However, no substantial increment in the decolorization efficiency could be achieved with further increases in residence time.

In the present study, low pressure UV lamps (15 watt) were used. The UV radiation applied for the decolorization of dye wastewater is usually measured in terms of $\mathrm{mW}-\mathrm{sec}^{-2}$ centimeter $\left(\mathrm{mW}-\mathrm{sec} \mathrm{cm}^{-2}\right)$. The effective UV dose used in this study varied from 30155 to $3015567 \mathrm{~mW}$-sec $\mathrm{cm}^{-2}$, which was smaller than the UV dose of 2812500-45000000 mW-sec $\mathrm{cm}^{-2}$ used by Abu Tariq et $a l^{[17]}$ and approximately within the ranges of 35640-39960 mW-sec $\mathrm{cm}^{-2}$ used by Akyol and Bayramoglu $^{[21]}$ and 194400-205200 mW-sec cm${ }^{-2}$ used by Mounir et al. ${ }^{[16]}$. The most commonly employed UV lamps for the wastewater treatment systems are low or medium pressure mercury lamps due to cost concerns ${ }^{[25]}$. However, it has been established that many chemical bonds of the targeted organic material cannot be broken directly due to the limitation of wavelengths not matching absorption bonds ${ }^{[26]}$.

Liao et $a l^{[27]}$ reported that dye solutions exposed to UV radiation only, achieved varying decolorization depending upon type of dye as well as UV intensities and contact time. Therefore, the UV degradation processes must be accompanied with oxidants/photocatalysts such as $\mathrm{H}_{2} \mathrm{O}_{2}, \mathrm{TiO}_{2}$ or ozone to generate active hydroxyl radicals to initiate autooxidation reactions for complete degradation ${ }^{[28,29]}$. According to Feng et al. ${ }^{[25]}$, addition of chemicals as oxidants could interfere with the process and thus recommended the application of dielectric barrier discharge (DBD) driven excimer lamps. Depending on the filling gas, DBD lamps can emit radiation into narrow-band or quasi-monochromatic spectrum with the required specific wavelength with respect to the concerned dye ${ }^{[30,31]}$.

$\mathrm{TiO}_{2}$ only: The efficiency of decolorization of Remazol brilliant blue by $\mathrm{TiO}_{2}$ coated coil reactor in absence of UV radiation is also shown in Fig. 6. A maximum decolorization efficiency of $2.6 \%$ was attained at the residence time of $84 \mathrm{~min}$. This low decolorization efficiency could be due to the absence of light source ${ }^{[14]}$. Activated by light source, $\mathrm{TiO}_{2}$ has been reported to be capable of degrading various organic pollutants completely according to the following reaction $^{[32]}$ :

$$
\mathrm{TiO}_{2}+\mathrm{hv} \rightarrow \mathrm{TiO}_{2}\left(\mathrm{e}^{-}+\mathrm{o}^{+}\right)
$$

Where:

$\mathrm{hv}=$ Radiation energy ( $\mathrm{mW}$-sec)

$\mathrm{e}^{-}=$Strong reducing species

$\mathrm{o}^{+}=$Strong oxidizing species

The degradation of organic dye, such as Remazol Brilliant Blue is resulted by the action of hydroxyl radical $\left(\mathrm{OH}^{*}\right)$, which can be formed by the oxidation of the adsorbed water. The complete photocatalytic oxidation reaction result into the final products $\mathrm{CO}_{2}$ and $\mathrm{H}_{2} \mathrm{O}^{[14]}$. Furthermore, the quantum yield for the photocatalytic reactions (defined as the number of degraded molecules divided by the number of photons absorbed by the system) is significantly affected by the intensity and wavelength of the radiation ${ }^{[33]}$.

$\mathrm{TiO}_{2} / \mathrm{UV}$ radiation: Several researchers have attempted to treat organic dye effluents using advanced oxidation processes $\left(\mathrm{TiO}_{2}\right.$ as catalyst in the presence of visible/UV radiation) with mixed results ${ }^{[14,16,34]}$. The possible reasons for low decolorization efficiencies reported by these researchers included: quantity of $\mathrm{TiO}_{2}$, dye concentration, intensity of UV source used and reactor configuration.

In order to investigate the effect of $\mathrm{TiO}_{2}$ coating, the coil reactor was operated with single and double coatings of $\mathrm{TiO}_{2}$ separately in the presence of UV radiation at a dye concentration of $300 \mathrm{mg} \mathrm{L}^{-1}$. The results of decolorization efficiencies obtained with different $\mathrm{TiO}_{2}$ coatings are shown in Fig. 6. Maximum decolorization efficiencies of 12.2 and $12.5 \%$ were achieved at a residence time $\leq 84 \mathrm{~min}$ for the single and double coatings, respectively. Student's t-test was performed on the data to test the differences between 


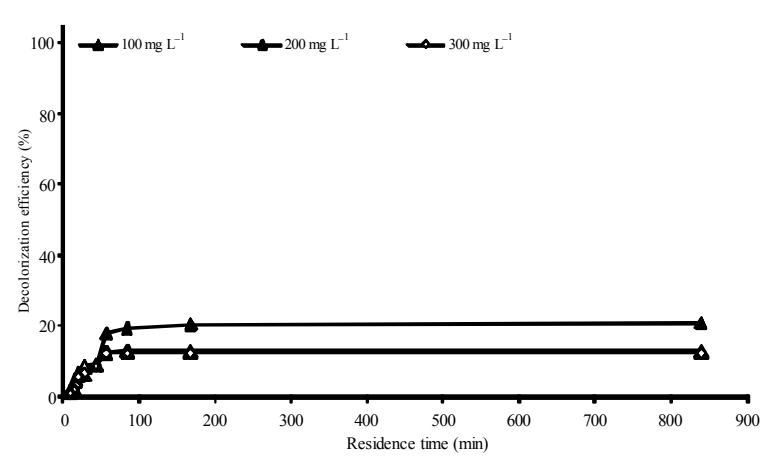

Fig. 7: Effect of $\mathrm{TiO}_{2} / \mathrm{UV}$ radiation on decolorization at various dye concentrations

coatings. No significant difference was found at $p>0.05$. Thus, it was concluded that the number of coatings did not affect the efficiency of decolorization.

The effect of dye concentration (100, 200 and 300

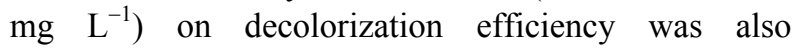
investigated. The results are presented in Fig. 7. The decolorization efficiency decreased with increase in dye concentration due to higher effective penetration of UV radiation in the dilute dye solution. The maximum decolorization efficiencies were $20.8,13.1$ and $12.5 \%$, for 100,200 and $300 \mathrm{mg} \mathrm{L}^{-1}$ dye concentrations, respectively.

Abu Tariq et al. ${ }^{[17]}$ achieved approximately 50 and $70 \%$ degradation of the textile dye compounds acid blue (142.3 $\left.\mathrm{mg} \mathrm{L}^{-1}\right)$ and xylenol orange $\left(228.2 \mathrm{mg} \mathrm{L}^{-1}\right)$ within $80 \mathrm{~min}$ in a $\mathrm{TiO}_{2} / \mathrm{UV}$ reactor with $\mathrm{TiO}_{2}$ suspension, respectively. Akyol and Bayramoglu ${ }^{[21]}$ reported complete decolorization of the azo-reactive textile dye Remazol Red F-3B $\left(150 \mathrm{mg} \mathrm{L}^{-1}\right)$ in a batch slurry $\mathrm{TiO}_{2} / \mathrm{UV}$ reactor. These authors used multiple lamps with constant stirring set-up and applied a centrifugation process to separate $\mathrm{TiO}_{2}$ catalyst particles after photocatalysis. Mounir et al. ${ }^{[16]}$ were able to decolorize approximately 99\% Basic Red 46 (10 and $25 \mathrm{mg} \mathrm{L}^{-1}$ ) at the end of $2 \mathrm{~h}$ treatment under sunlight using $\mathrm{TiO}_{2}$ catalysts fixed on a flexible support.

In the present study, $\mathrm{TiO}_{2}$ catalyst was fixed on the surface of the stainless steel coil. Although, this eliminated the need for centrifugation step, it resulted in lower quantity of the catalyst in comparison to $\mathrm{TiO}_{2}$ suspensions used by other authors. The lower decolorization efficiencies for the $\mathrm{TiO}_{2} / \mathrm{UV}$ coil reactor used in the present study, in comparison to those reported by Abu Tariq et al. ${ }^{[17]}$ and Akyol and Bayramoglu ${ }^{[21]}$ could, therefore, be due to lower quantity of $\mathrm{TiO}_{2}$ catalyst available on the coil. The dye concentration used in the present study was in the range of 100-300 $\mathrm{mg} \mathrm{L}^{-1}$. The higher dye concentrations, in

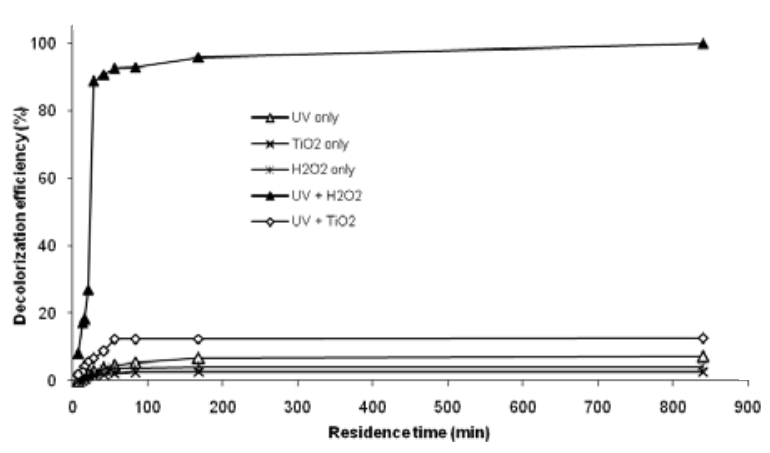

Fig. 8: Effect of UV, $\mathrm{TiO}_{2}$ and $\mathrm{H}_{2} \mathrm{O}_{2}$

comparison to that used by Mounir et al ${ }^{[16]}$ possibly also resulted in lower decolorization efficiency.

$\mathbf{H}_{2} \mathbf{O}_{2}$ only: A maximum decolorization efficiency of $4.07 \%$ was achieved at a residence time of $168 \mathrm{~min}$ when $\mathrm{H}_{2} \mathrm{O}_{2}$ was used in the absence of UV radiation with a dye concentration of $300 \mathrm{mg} \mathrm{L}^{-1}$ as shown in Fig. 8. The low decolorization efficiency was due to limitation of formation of hydroxyl radicals in absence of radiation energy ${ }^{[34]}$. The free hydroxyl radical $\left(\mathrm{OH}^{*}\right)$ is produced due to breakdown of $\mathrm{H}_{2} \mathrm{O}_{2}$ in the presence of radiation energy (UV radiation) as follows:

$$
\mathrm{H}_{2} \mathrm{O}_{2}+\mathrm{hv} \rightarrow 2 \mathrm{OH}^{\cdot}
$$

Photooxidation of the organic aromatic compound Remazol Brilliant Blue dye would require cleavages of functional groups such as amino, antrhaquinone, sulfo, sulfonyl, sulfoxy, ethyl and sufonic acid disodium salt by the free hydroxyl radicals produced from dissociation of $\mathrm{H}_{2} \mathrm{O}_{2}{ }^{[35]}$. The decolorization efficiency achieved when using $\mathrm{H}_{2} \mathrm{O}_{2}$ only was nominal as the $\mathrm{H}_{2} \mathrm{O}_{2}$ used in the present study contained stabilizer compounds, which limit the dissociation of $\mathrm{H}_{2} \mathrm{O}_{2}$ under standard conditions. Thus, in the absence of UV radiation, substantial degradation of Remazol Brilliant Blue dye was not observed even at optimal concentration of $\mathrm{H}_{2} \mathrm{O}_{2}$.

$\mathrm{H}_{2} \mathrm{O}_{2} / \mathbf{U V}$ radiation: The decolorization efficiencies increased significantly when $\mathrm{H}_{2} \mathrm{O}_{2}$ was used in the presence of UV radiation as shown in Fig. 8. A decolorization efficiency of $99.9 \%$ was achieved at a residence time of $42 \mathrm{~min}$. The effect of dye concentration $\left(100,200\right.$ and $\left.300 \mathrm{mg} \mathrm{L}^{-1}\right)$ on the decolorization efficiency was also investigated at different residence times $(840.0,168.0,84.0,56.0,42.0$, 28.0, 21.0, 16.8, 14.0 and $8.4 \mathrm{~min}$ ) as shown in Fig. 9. Decolorization efficiencies of $99.92,99.96$ and $99.90 \%$ 
were achieved at residence time of $42 \min$ for 100, 200 and $300 \mathrm{mg} \mathrm{L}^{-1}$, respectively. This was due to the formation of higher amount of free hydroxyl radicals by the dissociation of $\mathrm{H}_{2} \mathrm{O}_{2}$ in the presence of UV radiation ${ }^{[35]}$. The $\mathrm{H}_{2} \mathrm{O}_{2}$ concentration in the present study was based on the optimization study of Mahmoud et al. ${ }^{[19]}$. However, the $\mathrm{H}_{2} \mathrm{O}_{2}$ concentration could be further reduced for lower dye concentrations. In addition, utilization of moderate to high intensity UV radiation source would also minimize the chemical use.

Temperature profile: Table 1 shows the steady state temperatures at all residence times for single and double coatings of $\mathrm{TiO}_{2}$ with $\mathrm{UV}$ radiation at $300 \mathrm{mg}$ $\mathrm{L}^{-1}$ dye concentration. The temperature on the outside surface of the reactor opposite to outlet increased upto $54.7^{\circ} \mathrm{C}$, while the inlet dye solution temperature was $29.2{ }^{\circ} \mathrm{C}$. The temperature of the reactor decreased considerably with decrease in residence time. The difference in decolorization efficiencies of single and double coatings were not substantial. Therefore, no substantial differences in temperature profiles, due to the heat of the photochemical reaction of dye solution, were observed. $\mathrm{Wu}$ et $a l^{[36]}$ reported increase in decolorization of Reactive Blue 15 with temperature using ozone as advanced oxidizing agent due to corresponding increase in volumetric mass transfer coefficient. However, no significant effect on the temperature was observed for UV mediated processes as most photochemically induced reactions have low activation energy ${ }^{[37]}$.

The temperatures measured at the steady state conditions of the 2-coat $\mathrm{TiO}_{2} / \mathrm{UV}$ reactor using different dye concentrations are shown in Table 2. The temperatures were not affected by the dye concentration.

Table 3 shows the steady state temperature profiles of different locations of the double $\mathrm{TiO}_{2}$ coatings reactor with and without UV using $300 \mathrm{mg} \mathrm{L}^{-1}$ dye concentration. For the $\mathrm{TiO}_{2}$ reactor without UV, no significant temperature differences were observed at all locations. However, for the $\mathrm{TiO}_{2}$ reactor with $\mathrm{UV}$, the

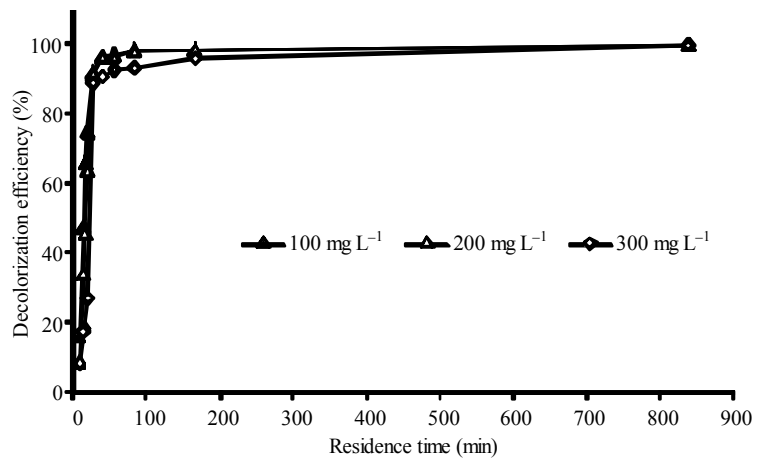

Fig. 9: Effect of $\mathrm{H}_{2} \mathrm{O}_{2} / \mathrm{UV}$ radiation on decolorization at various dye concentrations

Table 1: Steady state temperatures measured at different locations of $\mathrm{TiO}_{2} / \mathrm{UV}$ coil reactors with different $\mathrm{TiO}_{2}$ coatings using a dye concentration of $300 \mathrm{mg} \mathrm{L}^{-1}$

\begin{tabular}{|c|c|c|c|c|c|c|c|c|c|c|c|c|c|c|c|c|c|c|}
\hline \multirow{3}{*}{$\begin{array}{l}\text { Residence } \\
\text { time } \\
(\mathrm{min})\end{array}$} & \multicolumn{18}{|c|}{ Location of thermocouples } \\
\hline & \multicolumn{2}{|c|}{1} & \multicolumn{2}{|c|}{2} & \multicolumn{2}{|c|}{3} & \multicolumn{2}{|c|}{4} & \multicolumn{2}{|c|}{5} & \multicolumn{2}{|c|}{6} & \multicolumn{2}{|c|}{7} & \multicolumn{2}{|c|}{8} & \multicolumn{2}{|c|}{9} \\
\hline & A & B & A & B & A & B & A & B & A & B & A & B & A & B & A & B & A & B \\
\hline 840.0 & 41.0 & 39.6 & 49.5 & 49.9 & 54.7 & 53.3 & 52.0 & 52.4 & 52.4 & 52.0 & 49.8 & 47.1 & 48.4 & 49.1 & 29.2 & 28.2 & 30.4 & 30.5 \\
\hline 168.0 & 34.0 & 34.0 & 44.7 & 43.8 & 50.2 & 49.1 & 48.1 & 47.8 & 48.5 & 47.2 & 46.5 & 46.0 & 50.0 & 48.1 & 25.8 & 26.3 & 28.5 & 29.3 \\
\hline 84.0 & 29.8 & 30.3 & 37.6 & 37.8 & 43.1 & 43.3 & 41.5 & 42.4 & 42.0 & 42.0 & 40.4 & 41.1 & 43.7 & 43.1 & 25.7 & 26.2 & 27.3 & 28.5 \\
\hline 56.0 & 28.8 & 28.8 & 34.7 & 34.5 & 39.6 & 39.6 & 38.4 & 39.1 & 38.8 & 38.6 & 37.5 & 38.0 & 40.4 & 39.9 & 26.1 & 26.2 & 27.3 & 28.2 \\
\hline 42.0 & 27.6 & 27.8 & 31.9 & 32.2 & 35.2 & 35.5 & 34.3 & 35.1 & 34.6 & 34.8 & 33.6 & 34.3 & 35.9 & 36.1 & 25.6 & 26.0 & 26.8 & 27.9 \\
\hline 28.0 & 27.2 & 27.2 & 30.2 & 30.3 & 32.7 & 32.9 & 32.2 & 32.7 & 32.4 & 32.4 & 31.6 & 32.0 & 33.4 & 33.5 & 25.8 & 26.1 & 26.9 & 27.7 \\
\hline 21.0 & 27.1 & 26.9 & 29.3 & 29.1 & 31.5 & 31.1 & 31.2 & 31.2 & 31.4 & 30.8 & 30.6 & 30.6 & 32.1 & 31.6 & 26.1 & 26.0 & 26.9 & 27.4 \\
\hline 16.8 & 27.0 & 26.3 & 28.7 & 28.2 & 30.6 & 30.1 & 30.3 & 30.2 & 30.5 & 29.8 & 29.9 & 29.6 & 31.1 & 30.4 & 26.1 & 25.6 & 26.7 & 27.0 \\
\hline 14.0 & 25.7 & 26.3 & 27.0 & 27.7 & 28.2 & 28.7 & 28.4 & 28.9 & 28.4 & 28.5 & 28.0 & 28.3 & 28.6 & 28.7 & 24.9 & 25.7 & 26.5 & 26.8 \\
\hline 8.4 & 25.4 & 25.7 & 26.2 & 26.6 & 28.6 & 27.9 & 30.2 & 30.5 & 30.3 & 29.7 & 29.7 & 30.4 & 29.6 & 28.2 & 25.0 & 25.4 & 26.1 & 26.4 \\
\hline $\begin{array}{ll}\text { 1: } & \text { Tempe } \\
\text { 2: } & \text { Tempe } \\
\text { 3: } & \text { Tempe } \\
\text { 4: } & \text { Tempe } \\
\text { 5: } & \text { The in } \\
\text { 6: } & \text { Tempe } \\
\text { 7: } & \text { The ou } \\
\text { 8: } & \text { The in } \\
\text { 9: } & \text { The te } \\
\text { A: } & \text { The 1- } \\
\text { B: } & \text { The 2- }\end{array}$ & $\begin{array}{l}\text { erature } \\
\text { arature } \\
\text { rature } \\
\text { arature } \\
\text { side te } \\
\text { arature } \\
\text { itlet dy } \\
\text { let dy } \\
\text { mpera } \\
\text { coat } \\
\text { coat }\end{array}$ & $\begin{array}{l}\text { on the } \\
\text { on the } \\
\text { on the } \\
\text { of the } r \\
\text { nperatu } \\
\text { on the } \\
\text { e tempe } \\
\text { solutio } \\
\text { ure of } t \\
\mathrm{iO}_{2} \text { rea } \\
\mathrm{iO}_{2} \text { rea }\end{array}$ & $\begin{array}{l}\text { utside } \\
\text { utside } \\
\text { actor l } \\
\text { e of th } \\
\text { utside } \\
\text { rature } \\
\text { tempe } \\
\text { e lamp } \\
\text { tor } \\
\text { tor }\end{array}$ & $\begin{array}{l}\text { urface } \\
\text { urface } \\
\text { urface } \\
\text { ead spa } \\
\text { react } \\
\text { urface } \\
\text { rature } \\
\text { socket }\end{array}$ & $\begin{array}{l}\text { of the } \\
\text { of the } \\
\text { of the } \\
\text { ce } \\
\text { top } \\
\text { of the }\end{array}$ & ctor & $\begin{array}{l}\text { the } m \\
\text { posite }\end{array}$ & $\begin{array}{l}0 \text { inlet } \\
\text { height } \\
\text { o outle }\end{array}$ & & & & & & & & & & \\
\hline
\end{tabular}


Am. J. Engg. \& Applied Sci., 1 (3): 230-240, 2008

Table 2: Steady state temperatures measured at different locations of a 2-coat $\mathrm{TiO}_{2} / \mathrm{UV}$ coil reactor using different dye concentrations

\begin{tabular}{|c|c|c|c|c|c|c|c|c|c|c|c|c|c|c|c|c|c|c|c|c|c|c|c|c|c|c|c|}
\hline \multirow{3}{*}{$\begin{array}{l}\text { Residence } \\
\text { Time } \\
(\mathrm{min})\end{array}$} & \multicolumn{27}{|c|}{ Location of thermocouples } \\
\hline & \multicolumn{3}{|c|}{1} & \multicolumn{3}{|c|}{2} & \multicolumn{3}{|c|}{3} & \multicolumn{3}{|c|}{4} & \multicolumn{3}{|c|}{5} & \multicolumn{3}{|c|}{6} & \multicolumn{3}{|c|}{7} & \multicolumn{3}{|c|}{8} & \multicolumn{3}{|c|}{9} \\
\hline & A & B & $\mathrm{C}$ & A & B & C & A & B & $\mathrm{C}$ & A & $\mathrm{B}$ & C & A & B & $\mathrm{C}$ & $\mathrm{A}$ & B & C & A & B & $\mathrm{C}$ & A & B & C & A & B & $\mathrm{C}$ \\
\hline 840.0 & 37.1 & 36.7 & 39.6 & 47.2 & 43.8 & 49.9 & 52.3 & 46.9 & 53.3 & 52.2 & 47.5 & 52.4 & 50.6 & 47.2 & 52.0 & 49.1 & 46.1 & 47.1 & 48.8 & 48.6 & 49.1 & 26.6 & 26.2 & 28.2 & 29.2 & 29.5 & 30.5 \\
\hline 168.0 & 34.2 & 32.8 & 34.0 & 44.7 & 41.2 & 43.8 & 50.2 & 44.2 & 49.1 & 49.0 & 44.6 & 47.8 & 48.5 & 44.3 & 47.2 & 47.3 & 43.2 & 46.0 & 47.5 & 45.5 & 48.1 & 26.5 & 26.1 & 26.3 & 29.2 & 29.2 & 29.3 \\
\hline 84.0 & 30.2 & 29.8 & 30.3 & 37.9 & 36.6 & 37.8 & 43.3 & 40.1 & 43.3 & 42.6 & 40.6 & 42.4 & 42.2 & 40.3 & 42.0 & 41.3 & 39.4 & 41.1 & 43.9 & 41.3 & 43.1 & 26.3 & 26.0 & 26.2 & 28.1 & 28.5 & 28.5 \\
\hline 56.0 & 29.2 & 28.6 & 28.8 & 34.7 & 34.1 & 34.5 & 39.3 & 37.6 & 39.6 & 38.8 & 38.1 & 39.1 & 38.6 & 37.9 & 38.6 & 37.9 & 37.1 & 38.0 & 40.2 & 39.2 & 39.9 & 26.6 & 26.2 & 26.2 & 27.9 & 28.5 & 28.2 \\
\hline 42.0 & 28.7 & 27.8 & 27.8 & 32.1 & 32.1 & 32.2 & 36.8 & 34.8 & 35.5 & 36.4 & 35.3 & 35.1 & 36.2 & 35.0 & 34.8 & 34.5 & 34.5 & 34.3 & 37.6 & 36.2 & 36.1 & 26.1 & 26.1 & 26.0 & 27.9 & 28.2 & 27.9 \\
\hline 28.0 & 28.3 & 27.2 & 27.2 & 29.9 & 29.9 & 30.3 & 34.3 & 31.9 & 32.9 & 34.1 & 32.4 & 32.7 & 33.8 & 32.2 & 32.4 & 33.4 & 31.8 & 32.0 & 34.9 & 33.1 & 33.5 & 26.1 & 26.1 & 26.1 & 28.0 & 28.1 & 27.7 \\
\hline 21.0 & 28.2 & 27.0 & 26.9 & 29.1 & 29.1 & 29.1 & 32.6 & 31.2 & 31.1 & 32.5 & 31.7 & 31.2 & 32.2 & 31.5 & 30.8 & 31.9 & 31.2 & 30.6 & 33.2 & 32.1 & 31.6 & 26.2 & 26.2 & 26.0 & 28.0 & 28.1 & 27.4 \\
\hline 16.8 & 28.2 & 26.8 & 26.3 & 28.5 & 28.5 & 28.2 & 31.9 & 30.0 & 30.1 & 32.0 & 30.5 & 30.2 & 31.7 & 30.3 & 29.8 & 31.4 & 30.0 & 29.6 & 32.5 & 30.7 & 30.4 & 26.1 & 26.1 & 25.6 & 28.2 & 28.2 & 27.0 \\
\hline 14.0 & 28.0 & 26.7 & 26.3 & 28.2 & 28.2 & 27.7 & 31.3 & 29.2 & 28.7 & 31.5 & 29.8 & 28.9 & 31.1 & 29.5 & 28.5 & 30.9 & 29.4 & 28.3 & 31.7 & 29.7 & 28.7 & 26.1 & 26.1 & 25.7 & 28.4 & 28.6 & 26.8 \\
\hline 8.4 & 27.9 & 26.6 & 25.7 & 29.4 & 27.5 & 26.6 & 31.0 & 28.7 & 27.9 & 32.8 & 30.2 & 30.5 & 31.9 & 29.6 & 29.7 & 32.5 & 29.9 & 30.4 & 31.1 & 28.9 & 28.2 & 27.6 & 26.1 & 25.4 & 29.5 & 29.3 & 26.4 \\
\hline \multicolumn{28}{|c|}{ 1: $\quad$ Temperature on the outside surface of the reactor opposite to inlet } \\
\hline & & & & & & & & & & & & & & & & & & & & & & & & & & & \\
\hline 3: & perat & ture or & on the & outs & ide $\mathrm{s}$ & urfac & $\mathrm{e}$ of $\mathrm{t}$ & he re & actor & oppo & site $\mathrm{t}$ & o outl & & & & & & & & & & & & & & & \\
\hline 4: Tem & aperat & ture of & f the & react & tor he & $\mathrm{ead} \mathrm{sp}$ & pace & & & & & & & & & & & & & & & & & & & & \\
\hline 5: The & insid & le tem & aperat & ture c & of the & reac & tor to & & & & & & & & & & & & & & & & & & & & \\
\hline 6: Tem & uperat & ture or & on the & outs & ide $s$ & urfac & e of $t$ & he re & actor & top & & & & & & & & & & & & & & & & & \\
\hline 7: The & outle & et dye & temp & perat & & & & & & & & & & & & & & & & & & & & & & & \\
\hline 8: The & inlet & dye sc & soluti & ion te & mper & ature & & & & & & & & & & & & & & & & & & & & & \\
\hline 9: The & temp & eratur & Ire of & the 1 & amp & socke & et sur & face & & & & & & & & & & & & & & & & & & & \\
\hline A: at 10 & $00 \mathrm{mg}$ & $\mathrm{g} \mathrm{L}^{-1} \mathrm{C}$ & dye c & conce & entrat & & & & & & & & & & & & & & & & & & & & & & \\
\hline $\mathrm{B}:$ at 2 & $00 \mathrm{mg}$ & $\mathrm{g} \mathrm{L}^{-1} \mathrm{c}$ & dye c & conce & entrat & & & & & & & & & & & & & & & & & & & & & & \\
\hline C: at 3 & $0 \mathrm{~ms}$ & $\mathrm{~g} \mathrm{~L}^{-1} \mathrm{c}$ & d & conce & entra & & & & & & & & & & & & & & & & & & & & & & \\
\hline
\end{tabular}

Table 3: Steady state temperatures measured at different locations of 2-coat $\mathrm{TiO}_{2}$ coil reactor without $\mathrm{UV}$ using dye concentration of $300 \mathrm{mg} \mathrm{\textrm {L } ^ { - 1 }}$

\begin{tabular}{|c|c|c|c|c|c|c|c|c|c|c|c|c|c|c|c|c|c|c|}
\hline \multirow{3}{*}{$\begin{array}{l}\text { Residence } \\
\text { Time } \\
(\mathrm{min})\end{array}$} & \multicolumn{18}{|c|}{ Location of thermocouples } \\
\hline & \multicolumn{2}{|c|}{1} & \multicolumn{2}{|c|}{2} & \multicolumn{2}{|c|}{3} & \multicolumn{2}{|c|}{4} & \multicolumn{2}{|c|}{5} & \multicolumn{2}{|c|}{6} & \multicolumn{2}{|c|}{7} & \multicolumn{2}{|c|}{8} & \multicolumn{2}{|c|}{9} \\
\hline & A & B & A & B & A & B & A & B & A & B & A & B & A & B & A & B & A & B \\
\hline 840.0 & 27.2 & 39.6 & 27.3 & 49.9 & 27.4 & 53.3 & 27.7 & 52.4 & 27.6 & 52.0 & 27.6 & 47.1 & 27.6 & 49.1 & 26.6 & 28.2 & 27.6 & 30.5 \\
\hline 168.0 & 27.0 & 34.0 & 27.0 & 43.8 & 26.9 & 49.1 & 27.1 & 47.8 & 27.1 & 47.2 & 27.2 & 46 & 27.2 & .1 & 26.8 & 26.3 & 27.2 & 29.3 \\
\hline 84.0 & 26.8 & 30 & 26.8 & 37. & 26.7 & & & 42 & & 42 & 26.7 & & 26.8 & & 26.8 & & 26.9 & 28.5 \\
\hline 56.0 & 26.5 & 28.8 & 26.9 & 34.5 & 26.4 & 39.6 & 26.8 & 39.1 & 26.5 & 38.6 & 26.5 & 38.0 & 26.7 & 39.9 & 26.7 & 26.2 & 27.1 & 28.2 \\
\hline 42.0 & 26.3 & 27.8 & 27.0 & 32.2 & 26.3 & 35.5 & 26.7 & 35.1 & 26.4 & 34.8 & 26.4 & 34.3 & 26.5 & 36.1 & 26.6 & 26.0 & 27.0 & 27.9 \\
\hline 28.0 & 26.4 & 27.2 & 27.2 & 30.3 & 26.3 & 32.9 & 26.7 & 32.7 & 26.4 & 32.4 & 26.3 & 32.0 & 26.4 & 33.5 & 26.7 & 26.1 & 27.1 & 27.7 \\
\hline 21.0 & 26.3 & 26.9 & 27.1 & 29.1 & 26.2 & 31.1 & 26.5 & 31.2 & 26 & 30.8 & 26.3 & & & & 26.7 & 26.0 & 27.1 & 27.4 \\
\hline 16.8 & 26.1 & 26.3 & 27.1 & 28.2 & 26.1 & 30.1 & 26.5 & 30.2 & 26.1 & 29.8 & 26.3 & 29.6 & 26.1 & 30.4 & 26.7 & 25.6 & 27.0 & 27.0 \\
\hline 14.0 & 26.1 & 26.3 & 27.9 & 27.7 & 26.1 & 28.7 & 26.5 & 28.9 & 26.2 & 28.5 & 26.3 & 28.3 & 26.1 & 28.7 & 26.1 & 25.7 & 27.2 & 26.8 \\
\hline 8.4 & 26.1 & 25.7 & 29.2 & 26.6 & 26.3 & 27.9 & 27.7 & 30.5 & 27.4 & 29.7 & 27.7 & 30.4 & 26.3 & 28.2 & 26.4 & 25.4 & 27.8 & 26.4 \\
\hline
\end{tabular}

1: Temperature on the outside surface of the reactor opposite to inlet

2: Temperature on the outside surface of the reactor at the mid height

3: Temperature on the outside surface of the reactor opposite to outlet

4: Temperature of the reactor head space

5: The inside temperature of the reactor top

6: Temperature on the outside surface of the reactor top

7: The outlet dye temperature

8: The inlet dye solution temperature

9: The temperature of the lamp socket surface

A: Without UV

B: With UV

the temperature increased with residence time due to the removal of the heat produced by UV lamp. However, the temperature measurement could not be correlated with the decolorization efficiency due to the fact that photochemical reactions are effectively not sensitive to temperature changes around ambient values.

pH profile: Table 4 shows the $\mathrm{pH}$ values of inlet and outlet of the 2-coat coil reactor at steady state condition with and without UV radiation. The $\mathrm{pH}$ of the dye solution increased from 5.74 to 7.02 when the residence time was decreased from 840 to $8.4 \mathrm{~min}$. However, this $\mathrm{pH}$ change could not result in any significant change in decolorization efficiency. In general, the $\mathrm{pH}$ profiles also showed an increasing trend with increase in dye concentration as shown in Table 5. The changes in $\mathrm{pH}$ with dye decolorization could be mainly attributed to the formation of hydroperoxides (acidic entity) in the reacting solution during dye decolorization process ${ }^{[17]}$. 
Table 4: Inlet and outlet dye $\mathrm{pH}$ in $\mathrm{TiO}_{2} / \mathrm{UV}$ reactor at different operating conditions

\begin{tabular}{|c|c|c|c|c|c|}
\hline \multirow[b]{2}{*}{$\begin{array}{l}\text { Flow } \\
\text { rate } \\
\left(\mathrm{mL} \min ^{-1}\right)\end{array}$} & \multirow[b]{2}{*}{$\begin{array}{l}\text { Residence } \\
\text { time } \\
(\mathrm{min})\end{array}$} & \multicolumn{4}{|c|}{$\mathrm{pH}$} \\
\hline & & Inlet & $\begin{array}{c}\text { A } \\
\text { Outlet }\end{array}$ & $\begin{array}{c}\text { B } \\
\text { Outlet }\end{array}$ & $\begin{array}{c}\mathrm{C} \\
\text { Outlet }\end{array}$ \\
\hline 1 & 840.0 & 5.74 & 5.53 & 5.42 & 5.31 \\
\hline 5 & 168.0 & 6.41 & 5.68 & 5.66 & 5.96 \\
\hline 10 & 84.0 & 6.44 & 5.81 & 5.73 & 6.48 \\
\hline 15 & 56.0 & 6.72 & 6.09 & 5.84 & 6.60 \\
\hline 20 & 42.0 & 6.84 & 6.41 & 5.91 & 6.65 \\
\hline 30 & 28.0 & 6.87 & 6.74 & 6.34 & 6.72 \\
\hline 40 & 21.0 & 6.98 & 6.69 & 6.28 & 6.79 \\
\hline 50 & 16.8 & 6.99 & 6.78 & 6.85 & 6.84 \\
\hline 60 & 14.0 & 6.99 & 6.84 & 6.90 & 6.99 \\
\hline 100 & 8.4 & 7.02 & 6.85 & 6.86 & 7.00 \\
\hline
\end{tabular}

Table 5: Inlet and outlet dye $\mathrm{pH}$ in $\mathrm{TiO}_{2} / \mathrm{UV}$ reactor at different dye concentrations

\begin{tabular}{llllll}
\hline & & \multicolumn{4}{c}{$\mathrm{pH}$} \\
$\begin{array}{l}\text { Flow } \\
\text { rate } \\
\left(\mathrm{mL} \mathrm{min}^{-1}\right)\end{array}$ & $\begin{array}{l}\text { Residence } \\
\text { time } \\
(\mathrm{min})\end{array}$ & $\begin{array}{lll}\text { Inlet } \\
\text { In }\end{array}$ & $\begin{array}{c}\text { A } \\
\text { Outlet }\end{array}$ & $\begin{array}{c}\text { B } \\
\text { Outlet }\end{array}$ & $\begin{array}{c}\mathrm{C} \\
\text { Outlet }\end{array}$ \\
\hline 1 & 840.0 & 5.74 & 4.90 & 4.98 & 5.42 \\
5 & 168.0 & 6.41 & 5.04 & 5.18 & 5.66 \\
10 & 84.0 & 6.44 & 5.62 & 5.60 & 5.73 \\
15 & 56.0 & 6.72 & 5.71 & 5.80 & 5.84 \\
20 & 42.0 & 6.84 & 5.34 & 5.84 & 5.91 \\
30 & 28.0 & 6.87 & 5.86 & 6.09 & 6.34 \\
40 & 21.0 & 6.98 & 6.26 & 6.27 & 6.28 \\
50 & 16.8 & 6.99 & 6.35 & 6.51 & 6.85 \\
60 & 14.0 & 6.99 & 6.40 & 6.41 & 6.90 \\
100 & 8.4 & 7.02 & 6.76 & 6.83 & 6.86 \\
\hline
\end{tabular}

A: 2-coat with $\mathrm{UV}$ at $100 \mathrm{mg} \mathrm{L}^{-1}$ dye concentration

B: 2-coat with $\mathrm{UV}$ at $200 \mathrm{mg} \mathrm{L}^{-1}$ dye concentration

C: 2-coat with $\mathrm{UV}$ at $300 \mathrm{mg} \mathrm{L}^{-1}$ dye concentration

\section{CONCLUSIONS}

A coil photo reactor, consisting of a low range UV lamp and a spiral coil coated with $\mathrm{TiO}_{2}$, was used to investigate the decolorization of a synthetic effluent of Remazol Brilliant Blue dye. The effects of UV radiation, $\mathrm{TiO}_{2}$ coatings and dye concentration were studied and the results were compared to dye treatment involving $\mathrm{H}_{2} \mathrm{O}_{2}$. The single $\mathrm{TiO}_{2}$ coating using sol-gel technique was feasible for the dye treatment. The maximum dye removal efficiencies were 7.3, 12.2 and $12.5 \%$ for uncoated, single coat and dual coat of $\mathrm{TiO}_{2}$, respectively. The decolorization efficiency was inversely related to dye concentration of the effluent. The temperature varied from 29.2 to $54.7^{\circ} \mathrm{C}$ for $\mathrm{UV}+\mathrm{TiO}_{2}$ treatment and no change in reactor temperature was observed in the absence of UV. The $\mathrm{pH}$ profiles showed an increasing trend with increase in dye concentration. The treatments with UV only, $\mathrm{TiO}_{2}$ only, $\mathrm{UV}+\mathrm{TiO}_{2}, \mathrm{H}_{2} \mathrm{O}_{2}$ only and $\mathrm{UV}+\mathrm{H}_{2} \mathrm{O}_{2}$ resulted in color reduction of $7.6,2.3,12.5,4.1$ and $99.9 \%$ respectively. The maximum decolorization occurred in $\leq 100 \mathrm{~min}$ in all cases.

\section{ACKNOWLEDGEMENTS}

The research was funded by National Science and Engineering Council of Canada (NSERC). We also acknowledge the financial support provided by Killam Trusts of Dalhousie University in the form of Killam post doctoral fellowship to Dr. M. Verma.

\section{REFERENCES}

1. Mohan, N., N. Balasubramanian and C.A. Basha, 2007. Electrochemical oxidation of textile wastewater and its reuse. J. Hazardous Mater., 147: 644-651.

2. Reife, A. and H.S. Fremann, 1996. Environmental Chemistry of Dyes and Pigments. 1st Edn. John Wiley Inc., New York, NY.

3. Chan, L.S., W.H. Cheung and G. McKay, 2008. Adsorption of acid dyes by bamboo derived activated carbon. Desalination, 218: 304-312.

4. Al-Ghouti, M.A., M.A.M. Khraisheh, M.N. Ahmad and S.J. Allen, 2007. Microcolumn studies of dye adsorption onto manganese oxides modified diatomite. J. Hazardous Mater., 146: 316-327.

5. Kara, S., C. Aydiner, E. Demirbas, M. Kobya and N. Dizge, 2007. Modeling the effects of adsorbent dose and particle size on the adsorption of reactive textile dyes by fly ash. Desalination, 212: 282-293.

6. Qin, J.J., M.H. Oo and K.A. Kekre, 2007. Nanofiltration for recovering wastewater from a specific dyeing facility. Separat. Purificat. Technol., 56: 199-203.

7. Yu-li, Yuan, W. Yue-zhong, L. Xiao-ying and L. Si-zhen, 2006. Treatment of wastewater from dye manufacturing industry by coagulation. J. Zhejiang Univ. Sci. A., 7: 340 340-344.

8. Robinson, T., G. McMullan, R. Marchant and P. Nigam, 2001. Remediation of dyes in textile effluent: A critical review on current treatment technologies with a proposed alternative. Bioresour. Technol., 77: 247-255.

9. Lucas, M., V. Mertens, A.M. Corbisier and S. Vanhulle, 2008. Synthetic dyes decolourisation by white-rot fungi: Development of original microtitre plate method and screening. Enzyme Microbial Technol., 42: 97-106. 
10. Raghu, S. and C.A. Basha, 2007. Chemical or electrochemical techniques, followed by ion exchange, for recycle of textile dye wastewater. J. Hazardous Mater., 149: 324-330.

11. Ganesh, R., G.D. Boardman and D. Michelsen, 1994. Fate of azo dyes in sludges. Water Res., 28: 1367-1376.

12. Clover, B., 1993. Dyes. Environmental Chemistry. Reprinted from: Kirk-Othmer Encyclopedia of Chemical Technology. 4th Edn. John Wiley and Sons, Inc. New York, NY.

13. Bandala, E.R., M.A. Pelaez, A.J. Garcia-Lopez, M.D.J. Salgado and G. Moeller, 2008. Photocatalytic decolourisation of synthetic and real textile wastewater containing benzidine-based azo dyes. Chem. Eng. Process.: Process Intensificat., 47: 169-176.

14. Ibhadon, A.O., G.M. Greenway and Y. Yue, 2008. Photocatalytic activity of surface modified $\mathrm{TiO}_{2} / \mathrm{RuO}_{2} / \mathrm{SiO}_{2}$ nanoparticles for azo-dye degradation. Catalys Commun., 9: 153-157.

15. Gemeay, A.H., R.G. El-Sharkawy, I.A. Mansour and A.B. Zaki, 2008. Catalytic activity of polyaniline/MnO2 composites towards the oxidative decolorization of organic dyes. Applied Catalys. B: Environ., 80: 106-115. Doi: 10.1016/j. apcatb.2007.11.014.

16. Mounir, B., M.N. Pons, O. Zahraa, A. Yaacoubi and A. Benhammou, 2007. Discoloration of a red cationic dye by supported $\mathrm{TiO}_{2}$ photocatalysis. J. Hazardous Mater., 148 (3): 513-520.

17. Abu Tariq, M., M. Faisal, M. Saquib and M. Muneer, 2008. Heterogeneous photocatalytic degradation of an anthraquinone and a triphenylmethane dye derivative in aqueous suspensions of semiconductor. Dyes Pigments, 76: 358-365.

18. Colpini, L.M.S., H.J. Alves, O.A.A. Santos and C.M.M. Costa, 2008. Discoloration and degradation of textile dye aqueous solutions with titanium oxide catalysts obtained by the sol-gel method. Dyes Pigments, 76: 525-529.

19. Mahmoud, A.S., M.S. Brooks and A.E. Ghaly, 2007. Decolorization of remazol brilliant blue dye effluent by advanced photo oxidation process $\left(\mathrm{H}_{2} \mathrm{O}_{2} / \mathrm{UV}\right.$ system). Am. J. Applied Sci., 4: 1054-1062.

20. Adel, A., A. Idris, S. Katayon and C. Guan, 2004. Treatment of textile wastewater by advanced oxidation processes: A review. Global Nest: The Int. J., 6: 222-230.
21. Akyol, A. and M. Bayramoglu, 2008. The degradation of an azo dye in a batch slurry photocatalytic reactor. Chem. Eng. Process.: Process Intensificat., Doi:10.1016/j.cep. 2007.11.002.

22. Lachheb, H., E. Puzenat, A. Houas, M. Ksibi, E. Elaloui, C. Guillard and J.M. Herrmann, 2002. Photocatalytic degradation of various types of dyes (Alizarin S, Crocein Orange G, Methyl Red, Congo Red, Methylene Blue) in water by UV-irradiated titania. Applied Catalys. B: Environ., 39: 75-90.

23. Hoffmann, M.R., S.T. Martin, W. Choi and D.W. Behnemann, 1995. Environmental applications of semiconductor photocatalysis. Chem. Rev., 95: 69-96.

24. Giornelli, T., A. Lofberg and E. Bordes-Richard, 2006. Preparation and characterization of $\mathrm{VO}_{\mathrm{x}} / \mathrm{TiO}_{2}$ catalytic coatings on stainless steel plates for structured catalytic reactors. Applied Catalys. A: General, 305: 197-203.

25. Feng, X., S. Zhu and H. Hou, 2006. Investigation of $207 \mathrm{~nm}$ UV radiation for degradation of organic dye in water. Water SA, 32: 43-48.

26. Shen, Y.S. and D.K. Wang, 2002. Development of photoreactor design equation for the treatment of dye wastewater by $\mathrm{UV} / \mathrm{H}_{2} \mathrm{O}_{2}$ process. J. Hazardous Mater., B89: 267-277.

27. Liao, C., M. Lu, Y. Yang and I. Lu, 2000. UV catalyzed hydrogen peroxide treatment of textile wastewater. Environ. Eng. Sci., 17: 9-18.

28. Koch, M., A. Yediler, D. Lienert, G. Insel and A. Kettrup, 2002. Ozonation of hydrolyzed azo dye reactive yellow 84 (CI). Chemosphere, 46: 109-113.

29. Choi, I. and U. Wiesmann, 2004. Influence of mass transfer and chemical reaction on ozonation of azo dyes. Water Sci. Technol., 49: 37-43.

30. Mildren, R.P. and R.J. Carman, 2001. Enhanced performance of a dielectric barrier discharge lamp using short-pulsed excitation. J. Phys. D: Applied Phys., 34: L1-L6.

31. Hirose, K., H. Sugahara and H. Matsuno, 2002. Basic performance of VUV exposure systems using head-on type $\mathrm{Ar}_{2}{ }^{*}$ and $\mathrm{Kr}_{2}{ }^{*} \mathrm{DBD}$ excimer lamps. J. Lights Visible Environ., 26: 35-41.

32. Zhao, J. and X.D. Yang, 2003. Photocatalytic oxidation for indoor air purification: A literature review. Building Environ., 38: 645-654.

33. Jin, Z., X. Zhang, G. Lu and S. Li, 2006. Improved quantum yield for photocatalytic hydrogen generation under visible light irradiation over eosin sensitized $\mathrm{TiO}_{2}$-Investigation of different noble metal loading. J. Mol. Catalys. A: Chem., 259: 275-280. 
34. Li, X., C. Chen and J. Zhao, 2001. Mechanism of Photodecomposition of $\mathrm{H}_{2} \mathrm{O}_{2}$ on $\mathrm{TiO}_{2}$ Surfaces under Visible Light Irradiation. Langmuir, 17: 4118-4122.

35. Colonna, G.M., T. Caronna and B. Marcandali, 1999. Oxidative degradation of dyes by ultraviolet radiation in the presence of hydrogen peroxide. Dyes Pigments, 41: 211-220.
36. Wu, J., H. Doan and S. Upreti, 2008. Decolorization of aqueous textile reactive dye by ozone. Chem. Eng. J., doi:10.1016/j.cej.2007. 11.019 .

37. Galindo, C. and A. Kalt, 1998. UV- $\mathrm{H}_{2} \mathrm{O}_{2}$ oxidation of monoazo dyes in aqueous media: a kinetic study. Dyes Pigments, 40: 27-35. 